\title{
Viewing the capitalist world-system through (inter-)city lenses: rationale, methodology and first results
}

Een kijk op het kapitalistische wereld-systeem door een (inter-) stedelijke bril: rationale, methodologie en eerste resultaten

\section{Ben Derudder}

\section{OpenEdition}

\section{Journals}

\section{Electronic version}

URL: http://journals.openedition.org/belgeo/16717

DOI: 10.4000/belgeo.16717

ISSN: 2294-9135

\section{Publisher:}

National Committee of Geography of Belgium, Société Royale Belge de Géographie

\section{Printed version}

Date of publication: 30 September 2003

Number of pages: 269-288

ISSN: 1377-2368

\section{Electronic reference}

Ben Derudder, "Viewing the capitalist world-system through (inter-)city lenses: rationale, methodology and first results", Belgeo [Online], 3 | 2003, Online since 30 October 2003, connection on 05 February 2021. URL: http://journals.openedition.org/belgeo/16717 ; DOI: https://doi.org/10.4000/belgeo.16717

This text was automatically generated on 5 February 2021.

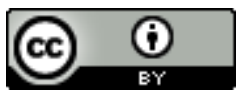

Belgeo est mis à disposition selon les termes de la licence Creative Commons Attribution 4.0 International. 


\title{
Viewing the capitalist world-system through (inter-)city lenses: rationale, methodology and first results
}

\author{
Een kijk op het kapitalistische wereld-systeem door een (inter-) stedelijke bril: \\ rationale, methodologie en eerste resultaten
}

Ben Derudder

I would like to thank the Fund for scientific Research (FWO) for the travel grant I was awarded for a one-month stay at Loughborough University. Piet Saey is thanked for useful remarks.

\section{Introduction: rationale for a city-based approach to world-systems analysis}

1 According to Immanuel Wallerstein (2000, pp. 129-48), the capitalist world-economy is a system that involves a hierarchical and a spatial inequality of distribution based on the concentration of certain kinds of production in certain limited zones, which thereupon and thereby become the loci of the greatest accumulation of capital. The division of labour which characterizes this spatial inequality is materialized through a tripolar system, in which these «certain limited zones» are referred to as the core of the world-economy (in addition to semi-peripheral and peripheral zones), and these «certain kinds of production» involve relatively monopolized and therefore high-profit production. Capitalism, Wallerstein (2000, p. 141) asserts, should therefore be conceived as a historical social system that (i) reproduces spatial inequality and (ii) is inherently anti-market.

2 The concentration of accumulated capital in core zones of the world-economy has enabled the reinforcement of state structures, which have in turn sought to guarantee the survival of relative monopolies through policies such as protectionism, 
imperialism, corporatism and so forth. Although this makes the inter-state system a likely candidate to map the tripartite division of the capitalist world-system (e.g. Snyder and Kick, 1979; Arrighi and Drangel, 1986; Terlouw, 1992) ${ }^{1}$, it can readily be seen that this approach introduces some problematic assumptions. Countries such as China, for instance, are classified as either semi-peripheral (e.g. Terlouw, 1992) or peripheral (e.g. Snyder and Kick, 1979) as a whole, and this despite profound intra-state disparities in «development». It is evident that such «internal» disparities are present in any country, since core-periphery processes are always articulated simultaneously at a whole range of scales (Hanna, 1995, p. 453; De Wachter, 2002, pp. 54-58). However, in the case of China, the thoroughness of this «internal» spatial inequality seems to straddle the core-periphery contradictions within the capitalist world-system at large. That is, ranging from an affluent region near Hong Kong, over «developing» regions near Beijing and Shangai, and subsequently to «underdeveloped» regions in central and western parts of the country, it can be noted that all zonal articulations of the worldeconomy's inherent spatial inequality are represented. As a consequence, China's designation as a (semi-)peripheral area can be no more than a rather meaningless summary of incongruent processes.

3 In the present paper, we seek how the shortcomings induced by an exclusive focus on states may be overcome through a focus on the role city-regions play in the worldeconomy. This attention for city-regions can be implicitly traced back to the work of Giovanni Arrighi, who has presented an alternative conceptualisation of the capitalist world-economy. Drawing on earlier writings by Braudel and Tilly, Arrighi (1994, p. 84) has put forward that the spatial development of the modern capitalist world-system lies in the interdependent and often contradictory development of a system of territorial states and a system of non-territorially organised business networks ${ }^{2}$. The gist of his analysis is therefore that the expansion of capitalist power over the last five hundred years has been associated not just with inter-state competition for mobile capital, but also with the organizational capabilities of capitalist agencies that try to prevent individual states from reaping disproportionate parts of the accumulated capital: «capitalism as a world-system of accumulation and rule has developed simultaneously in [two] spaces. In the space-of-places, it triumphed by becoming identified with particular states. In the space-of-flows, in contrast, it triumphed by not becoming identified with any particular state but by constructing world-encompassing, non-territorial business organizations.» In the latter space-of-flows, cities derive their ontological status from their role as the basing points in multifarious flows that transcend individual political units (i.e. states). That is, urban networks provide the spatial infrastructure that enables capitalist agencies to overcome the fragility of monopolistic accumulation strategies at the state level, since cities are «the points at which maximum information about trading opportunities and a maximum range of goods were brought together and developed into a more elaborate form as trade became as much a problem of organizing capital flows and investments. Over and above patterns of trade and production, these centres act as base-points for the system at large, helping to route capital in the direction of opportunity» (Dodgshon, 1998, pp. 196-7).

4 When reference is made to a city's role as a crucial node in global flows, it is commonly deemed a «world city» or a "global city». More specifically, Friedmann (1995, p. 22) has defined world cities as centres «through which flow money, workers, information, commodities», and thereby articulate the «economic relations of their surrounding 
«field» or region into the global economy.» Although the incorporation of world cities in an analysis of the capitalist world-system implies the updating of Wallerstein's (1979) familiar ontological cast of households, classes, nations, and states, it is imperative that the latter remains implicated in such an analysis. Seoul's rise within the world-system's city-system, for instance, cannot be appropriately understood without making reference to the complex interplay between the vigorous «development» policies pursued by the South Korean state and the containment policy pursued by the hegemonic United States after World War II (Hill and Kim, 2000). Although it is thus the dialectical relation between the spatial genealogies of the «space-of-flows» and "the space-of-places» that forms the hallmark of the capitalist world-economy, this paper will solely focus on the spatial structure created by nonterritorially organised business organizations. Furthermore, the historical framework of world-systems analysis, as epitomized by Braudels longue durée, will be set aside in favour of a static, contemporary mapping of the world-system's city-system.

\section{The difference a hyphen makes: from world cities to world-cities}

\section{World cities as a research agenda}

5 This plea for an analysis of a network of world cities can hardly be conceived as the call for a new research agenda. Already back in the 80s, Cohen (1981), Friedmann and Wolff (1982) and especially Friedmann (1986) posited that there was a network of world cities. These first accounts gave way to a rapid rise in world city research in the 90s, with Sassen's (1991) account of London, New York, Tokyo, and the volume edited by Knox and Taylor (1995) arguably being the most influential contributions. And finally, in recent years world city research has established itself as one of the most important fields in human geography at large. In ISI's Essential Science Indicators of the year 2002 , for instance, world city research has been designated as one of the most vibrant research fields in the Social Sciences, with Taylor's (2000) review article as the most highly quoted example (http://esi-topics.com/erf/index.html).

6 At first sight, this brief overview suggests that there is a wealth of literature on which a networked description of the capitalist world-economy can directly be built. There are, however, at least two distinct problems with this rapidly expanding body of literature from a world-systems point of view. First, a whole range of world city studies have taken up with other theoretical frameworks, such as post-structuralism, actor-network theory, non-representational theory, complexity theory, etc., and are therefore of no use for the discussion at hand. Smith (2003b, p. 565), for instance, has ascertained that «Deleuze can help us conceptualise world city topologies because he gave much thought to the idea of space-time as folded. Deleuze's poststructuralist philosophy is one where boundaries, scales, and territories vanish through deterritorialization as the world is conceptualised as a living dermis with an infinite bundle of (un)folds and surfaces that make space and time.» Deleuze may help Smith $(2003 a, b)$ in conceptualising world cities, but this kind of world city research can hardly be seen as a useful source for advancing our understanding of the capitalist world-system.

7 The second problem with the existing body of world city literature is somewhat subtler, and can be traced back to the observation that the existing references to world-systems 
analysis are hardly convincing. In his seminal World City Hypothesis, Friedmann (1986) suggested a world city taxonomy in which world cities are deemed to be located in the core and to a lesser degree in the semi-periphery of the world-economy ${ }^{3}$. Saey (1996, p. 122 , translated from the original), however, has questioned whether this apparent spatial correlation is in and by itself sufficient to speak of a systematic relation between both structures:

«World city researchers (...) often refer to Wallerstein's world-systems analysis. A closer look, however, reveals that it would be wrong to designate the latter theory as the theoretical foundation of world city research. Setting aside a number of exceptions, world city research limits itself to adopting a tripolar world-system (core semi-periphery, periphery) defined on the basis of transnational divisions of labor and commodity chains. One can hardly speak of an analytical crossfertilization.»

8 Taylor (2000, p. 6), in his analysis of the theoretical and empirical foundations of world city research, has come to a similar conclusion:

«In his initial formulation, John Friedmann (1986) set world cities within a worldsystems framework with cities as the 'basing points' of capital in the worldeconomy. But world-systems analysis implies much more than locating cities in core or semi-periphery.»

9 At the most basic level, the critique by Saey (1996) and Taylor (2000) can be traced back to their dismay over the fact that the conceptual link between the world city network and core processes in a capitalist world-system is limited to their apparent (and indeed commonsensical) coincidence. As a consequence, it can be noted that the title of Knox' and Taylor's (1995) World Cities in a World-System reflects an ambition rather than a reality. Setting aside the observation that world cities are rarely conceptualised within a longue durée framework as put forward by world-systems analysis, the most pressing problems are (i) the lack of theoretical cross-references between world city research and world-systems analysis and (ii) the suggestive nature of the existing empirical world city taxonomies. Although both problems are of course heavily inter-related, we will treat them in a different section. The remainder of the present section looks at possible theoretical cross-references, the next section addresses the dearth of a suitable empirical approach.

\section{The monopoly of place}

In order to arrive at a world-systems approach, we will envisage world cities as antimarket nexuses that act as the command-and-control centers of the capitalist worldsystem. That is, rather than merely being some sort of spatial infrastructure that enables the efficient servicing of global capital, the world city network will be conceptualized as forming part and parcel of networks of capital accumulation and circulation, a system that enables capitalist agencies to stay above markets. This reenvisaging of some of the existing world city-narratives will be mainly drawn from the work by Sassen $(1995,2000)$ and Storper $(1997)$, who have interpreted world cities as knowledge-rich matrixes of business, banking, professional and creative agents.

The starting point for Sassen's $(1995,2000)$ account of world cities lies in an analysis of the (apparently) contradictory trends of spatial dispersal and concentration in the global economy. Although information technology has opened up the possibility for the dispersal of economic activities, it can readily be seen that this has in turn created a 
new form of centralisation of especially business service firms in a limited number of world cities. This spectacular rise in business service firms can be traced back to the observation that a growing number of manufacturing and service industries, unable to cope with the accelerated pace of structural change and the increasing pressure for product innovation on their own, are becoming more and more dependent on specialized outsourcing. The centralisation of these a-territorially organised business organisations ${ }^{4}$ in a limited number of world cities is in turn due to the fact that business firms obtain agglomeration economies when they locate close to other sellers of key inputs or joint producers of certain service offerings. Sassen (1995, pp. 67-68) has therefore stated that world cities should be conceived in the context of the vast multinational networks created by firms that provide advanced producer services. Apart from the obvious example of financial services, Sassen discerns services such as accountancy, advertising, insurance, and commercial law, which lie at the root of complexes of theoretical and practical knowledges as epitomized by London, New York and Tokyo.

Like Sassen, Storper (1997) has argued that enabling technologies have not resulted in economic dispersion, but rather in particular concentrations of economic activities. According to Storper, the global economy is characterized by reflexive economics in which to be successful entrepreneurs have to be part of a knowledge-rich, continual learning process. Such processes can only be collective and very specific to different places: they result in local assets, which are difficult to duplicate elsewhere. Using a traditional export base theory of urban activity, Storper argues that the economic activities involved in export are more reflexive in nature than those meeting local needs. The result is a pattern of overlapping worlds of knowledge and learning which produces specialised and designated commodities in both manufacturing and services for international markets. In these processes, cities converge in their increasing economic reflexivity while simultaneously diverging in their specificities (i.e. the particularity of the mixes of intellectual resources available in a given urban context). For Storper (1997, p. 222), it is just such ensembles of localized relations that give contemporary world cities their «very usefulness to the forces of global capitalism.»

Although Storper does not follow Sassen in her narrow focus on advanced producer services, it can be seen that both are giving great weight to the production of new and innovative services in which the reflexivity of the intellectual worlds is crucial. In spite of all their differences and disagreements, then, Sassen and Storper provide quite comparable explanations of why world cities are prospering as places in a capitalist world-economy. That is, the regional assets articulated in world cities enable capitalist agencies to stay above economics rather than operating in markets that keep prices down. These regional assets have been designated by Scott $(1997$, p. 325) as «the monopoly powers of place», and world cities are a specific case of such regional antimarket nexuses, i.e. power configurations that enact as the command-and-control centers for the spatial organisation of capital accumulation (Taylor, 2000). The world city network, then, is an inter-connected web of places where multifarious information and knowledge is available to seize economic opportunities through innovations in production, distribution or consumption. The bottom line in this conceptualisation is that world cities should not so much be conceived in their roles as trading sites, ports, banking centres or industrial towns, but rather as integral parts of complex networks of capital circulation and accumulation. This reading of world cities as anti-market nexuses in the spatial organisation of capital circulation and accumulation bears 
resemblance to Wallerstein's (1993, p. 295) call for the crucial hyphen in the concepts «world-economy» and «world-system»:

«My 'world-system' is not a system 'in the world' or 'of the world'. It is a system

'that is a world'. Hence the hyphen, since 'world' is not an attribute of the system.

Rather the two words constitute a single concept.»

Similarly, the world city network is not an attribute of a capitalist world-system. World cities integrate and reproduce the world-economy rather than merely being some sort of spatial infrastructure that stems from capitalism's internal logic. As a consequence, we will henceforth follow Wallerstein's terminology, and add the hyphen in our treatise of world-cities to acknowledge that we do in fact envisage something else than, say, a post-structuralist approach to world cities.

We must, however, be careful not to reify the world-city region in such an approach (Taylor, 2002). World-cities, of course, do not of themselves create economies. The agents of economic change are the holders of capital and it is their decisions that are vital for economic growth or stagnation. The fact that these agents congregate massively in relatively few cities implies that relations in transnational urban networks are not decided upon at the nodal level. Rather world-cities are «interlocked» by subnodal agents, i.e. by business interests that define both city economies and their network. It is this interlocking multiplied manifold that creates a world-city network as the basic spatial organization of a world-economy.

The next section addresses - explicitly based on this reading of the literature - the second problem with studies such as Friedmann's (1986) World City Hypothesis, i.e. the suggestive character of their empirical framework.

\section{Methodology: inferring relations between world-cities}

\section{The dirty little secret of world city research}

17 Most empirical world-city studies have been relying on a variety of commonsensical indicators, such as a world-city's role as a headquarter for TNCs and international institutions, its function as major transportation node, its rise as a global service centre, etc. (e.g. Cohen, 1981; Friedmann, 1986, 1995; Knox, 1995, Godfrey and Zhou, 1999). Although all these world-city lists are quite similar and inherently plausible, they all share one common deficit. That is, each list has in fact a highly suggestive character due to the dearth of relational data (Taylor, 1997, 1999a), a shortcoming that has been addressed by Short et al. (1996) as «the dirty little secret of world city research». The bottom line is that it seems logic to designate London and New York as two important world-cities based on what is retained within them (i.e. attribute data such as the number of corporate headquarters), but there has been a general lack of evidence on the myriad of flows between them (i.e. relational data such as information flows). To use Arrighi's (1994) and Castells' (1996) «space-of-flows» terminology: most world city research is studying the nodes in spaces of flows without reference to the flows themselves.

This evidential deficit can be traced back to the fact that «statistics» tend to be «stateistics», i.e. to get an evidential handle on big issues, researchers normally rely on data which are usually collected by a state agency for the particular needs of government policy rather than for social science research. The result is that the available data have 
an attributional bias and are limited to national territories. Where official statistics do extend beyond a state's boundaries, they will still use countries as the basic units (e.g. trade data), and, as a consequence, relations between world-cities do not feature in conventional statistical sources (Taylor, 1997, 1999a). This is the basic reason why the information needed for describing the world-city network is not readily available, and it is thus no surprise that social network analysis in urban studies has focused on smallscale networks (Derudder and Taylor, 2003).

\section{Formal network specification}

The Globalization and World Cities Group and Network (GaWC) has been set up at Loughborough University (UK) to overcome this relational data deficiency problem. Following Sassen (1995, 2000), GaWC treats world-cities as global service centres in multifarious networks, and the world-city network as a whole is formally specified as an inter-locking network with three levels (Taylor, 2001; Derudder et al., 2003): a network level (the world-economy), a nodal level (world-cities), and a critical sub-nodal level (firms providing the advanced producer services). It is at the latter level that world-city network formation takes place. Through their attempts to provide a seamless service to their clients across the world, financial and business service firms have created global networks of offices in cities around the world. Each office network represents a firm's strategy for servicing global capital, and the world-city network is thus formally specified as the amalgam of the office networks of global service firms. The «office towers» within cities are the knots between which there are flows of information, knowledge, ideas, personnel and instructions that connect world-cities in the world-economy ${ }^{5}$.

Based on this identification as an interlocking network, the world-city network has been formally specified (Taylor, 2001; Derudder and Taylor, 2003). Here we present the basic elements as an introduction to the subsequent data collection, which will in turn be used in the next section as the starting point for an exploratory analysis of the world-city network. The formal specification of the world-city network starts with a universe of $m$ advanced producer service firms in $n$ world cities. The importance of the office of a firm $j$ in city $i$ is measured through its «service value» vij, which can be arrayed as a service value matrix Vij. Assuming there is no actual information on interoffice flows for firms across cities, the basic relational element rab,j for each pair of cities $a, b$ in terms of a firm $j$ is derived from the initial matrix $\mathbf{V i j}$ as follows:

$$
\boldsymbol{r}_{a b, j}=\boldsymbol{v}_{a j} \cdot \boldsymbol{V}_{b j}
$$

(1)

The conjecture behind conceiving this elemental interlock link as a surrogate for actual flows of inter-firm information and knowledge between cities is that the more important the office, the more connections there will be with other offices in a firm's network. Although the nature of this calculation invokes a methodological uncertainty, we feel this approach is built on a number of reasonable assumptions. That is, the multiplicative assumptions that lie at the basis of computing rab,j seem sensible when the following suppositions are made (Taylor et al., 2001). First, offices generate more flows within a firm's network than to other firms in their sector. This has not yet been 
empirically tested but is inherently plausible. For instance, drawing up an interjurisdictional contract by a law firm will involve flows of information and knowledge between offices of that firm to achieve the ideal seamless service. Second, the more important the office, the more flows are generated and these have a multiplicative effect on inter-city relations. The first part of this assumption is very plausible again. The second part reflects the hierarchical nature of office networks where larger offices have special functions like control and provision of specialised knowledge. The main point is that without evidence of actual flows there is no easy means of estimating this effect, and a multiplicative process is a reasonably simple way to reflect the importance of major offices in the world-city network.

21 Each world-city has $\mathrm{n}-1$ links rab,j, and the aggregate city interlock link across all firms is then produced from:

$$
r_{a b}=\sum_{j} r_{a b, j}
$$

(2)

In order to take full advantage of all the dyadic information available from equation (2), we need to consider all relations to ascertain the systemic patterning of nodes and linkages. This requires the creation of a square $\mathrm{n} \times \mathrm{n}$ relational matrix $\mathbf{E}$ using the city interlock link rab for all city pairs. This elemental relational matrix is more interpretable if transformed into a proportionate relational matrix $\mathbf{P}$ where linkages are given as proportions of the maximum possible linkage. This maximum is:

$$
H=\sum_{j} h_{j}^{2}
$$

(3)

where hj is the highest service value provided by firm $\mathbf{j}$ across all cities. Matrix $\mathbf{P}$ is then the array of all $\mathrm{n} \times \mathrm{n}$ proportional city interlinks, and can be conceived as the persistent relationships that arise from aggregated effects of the interactions between the firms through the seamless service they wish to provide.

$$
p_{a b}=r_{a b} / H
$$

(4)

Finally, to complete specification of these relational matrices it is necessary to define the matrix diagonal as the "self-relation» of each city, which is not asserted in equations 2 and 4. For dimensional equivalence these self-relations are defined as: 


$$
r_{a}=\sum_{j} v_{j a}^{2}
$$

(5)

for matrix $\mathbf{E}$ and

$$
p_{a}=r_{a} / H
$$

(6)

for matrix $\mathbf{P}$.

The individual relations of any city can be aggregated to produce a city's global network connectivity as follows:

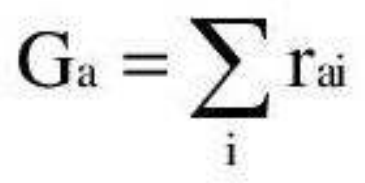

( $a^{1}$ i) (7)

The limiting case is a city that shares no firms with any other city, so that all of its elemental links are 0 and it has zero connectivity. These overall connectivity measures will be used in section 4 to order cities hierarchically, whereby $G$ will be expressed as a proportion of the largest computed connectivity in the data, thus creating a scale from 0 to 1 . Although it can readily be seen that the required data input for this specification follows Sassen's rather narrow conceptualisation of world-cities as global service centers, it has a distinct advantage when compared to the attributional approaches taken by authors such as Friedmann (1986). That is, contra previous explorations, this approach entails a relational specification: a city that harbours a large amount of advanced producer service firms that have a limited global reach will not be deemed as an important world-city in this approach.

\section{Empirical specification}

This theoretical specification has guided the data collection, which focused on the city office networks of global service firms. A fuller description of the rationale behind the selection of firms and cities can be found in Taylor et al. (2002); here we focus on the main conclusions from this analysis. Global service firms were defined as firms with offices in 15 or more different cities, and firms meeting this criterion were selected from rankings of leading firms in different service sectors. In the event 100 firms were identified in six sectors: 18 in accountancy, 15 in advertising, 23 in banking/finance, 11 in insurance, 16 in law, and 17 in management consultancy. Capital cities of all but the smallest states were included plus many other important cities in larger states, yielding a total of 234 cities for analysis ${ }^{6}$. The data collection focused on two features of a firm's office(s) in a city: first, the size of office (e.g. number of practitioners), and second, 
their extra-locational functions (e.g. regional headquarters). The main problem with this type of data collection exercise is that the exact nature of the information collected for each firm differed to that for every other firm. The solution was to standardize the information. Information for every firm was simplified into «service values» ranging from 0 to 5 as follows. The city housing a firm's headquarters was scored 5 , a city with no office of that firm was scored 0. An «ordinary» or «typical» office of the firm resulted in a city scoring 2 . With something missing (e.g. no partners in a law office), the score reduced to one. Particularly large offices were scored 3 and those with important extra-territorial functions (e.g. regional offices) scored 4. Applying formulas 1 through 7 on the initial $234 \times 100$ matrix Vij with vij ranging from 0 to 5 , a $234 \times 234$ proportional relational matrix $\mathbf{P}$ was constructed. To get a feel for the structure in the data, Tables 1-3 provide excerpts of $\mathbf{V i j}, \mathbf{P}$, and $\mathbf{G}$, while Figure 1 presents a visualization of some of the most important nodes and relations in the world-city network ${ }^{7}$.

Table 1. Excerpt of $234 \times 100$ matrix Vij.

\begin{tabular}{|c|c|c|c|c|c|}
\hline $\begin{array}{l}\text { Ernst \& } \\
\text { Young }\end{array}$ & $\begin{array}{c}\text { Arthur } \\
\text { Andersen }\end{array}$ & MSI & IGAF & $\begin{array}{c}\text { AGN } \\
\text { Network }\end{array}$ & BDO \\
\hline
\end{tabular}

\begin{tabular}{lllllllll}
\hline Amsterdam & 2 & 2 & 0 & 0 & 2 & 2 & 2 & $\ldots$ \\
Atlanta & 3 & 3 & 2 & 3 & 2 & 0 & 1 & $\ldots$ \\
Bangkok & 0 & 0 & 2 & 0 & 1 & 2 & 2 & $\ldots$ \\
Barcelona & 2 & 2 & 2 & 2 & 2 & 0 & 0 & $\ldots$ \\
Beijing & 0 & 2 & 0 & 0 & 0 & 1 & 2 & $\ldots$ \\
Berlin & 0 & 2 & 0 & 2 & 2 & 0 & 0 & $\ldots$ \\
Boston & 3 & 2 & 3 & 3 & 0 & 0 & 1 & $\ldots$ \\
$\ldots$ & $\ldots$ & $\ldots$ & $\ldots$ & $\ldots$ & $\ldots$ & $\ldots$ & $\ldots$ & $\ldots$ \\
\hline
\end{tabular}

Table 2. Excerpt of $234 \times 234$ matrix $P$.

\begin{tabular}{lllllllll} 
& Amsterdam & Atlanta & Bangkok & Barcelona & Beijing & Berlin & Boston \\
\hline Amsterdam & 0,2056 & 0,1036 & 0,1248 & 0,1072 & 0,1244 & 0,0968 & 0,0784 \\
Atlanta & 0,1036 & 0,1184 & 0,07 & 0,0812 & 0,0716 & 0,0616 & 0,0908 & $\ldots$ \\
Bangkok & 0,1248 & 0,07 & 0,1352 & 0,0712 & 0,1004 & 0,0644 & 0,0568 & $\ldots$ \\
Barcelona & 0,1072 & 0,0812 & 0,0712 & 0,1104 & 0,0728 & 0,0672 & 0,068 & $\ldots$ \\
Beijing & 0,1244 & 0,0716 & 0,1004 & 0,0728 & 0,1256 & 0,0668 & 0,0548 & $\ldots$ \\
Berlin & 0,0968 & 0,0616 & 0,0644 & 0,0672 & 0,0668 & 0,1056 & 0,0492 & $\ldots$ \\
Boston & 0,0784 & 0,0908 & 0,0568 & 0,068 & 0,0548 & 0,0492 & 0,1264 & $\ldots$ \\
$\ldots$ & $\ldots$ & $\ldots$ & $\ldots$ & $\ldots$ & $\ldots$ & $\ldots$ & $\ldots$ & $\ldots$ \\
\hline
\end{tabular}


Table 3. Excerpt of GNC measures (expressed as proportions of largest GNC in database).

\begin{tabular}{lc} 
City & GNC \\
\hline & \\
\hline London & 1 \\
New York & 0,97627723 \\
Hong Kong & 0,70690389 \\
Paris & 0,69911197 \\
Tokyo & 0,69056294 \\
Singapore & 0,64526254 \\
Chicago & 0,61554599 \\
Milan & 0,60355842 \\
Los Angeles & 0,59952050 \\
Toronto & 0,59461506 \\
Madrid & 0,59448887 \\
Amsterdam & 0,59013549 \\
Sydney & 0,57841606 \\
Frankfurt & 0,56726447 \\
Brussels & 0,55712235 \\
Sao Paulo & 0,54093913 \\
San Francisco & 0,50754744 \\
Mexico City & 0,48600136 \\
Zurich & 0,48481837 \\
Taipei & 0,47708954 \\
\hline$\ldots$ & $\ldots$. \\
\hline & \\
\hline & \\
\hline
\end{tabular}

Figure 1. Visualization of the most important modes and relations on the world-city network.

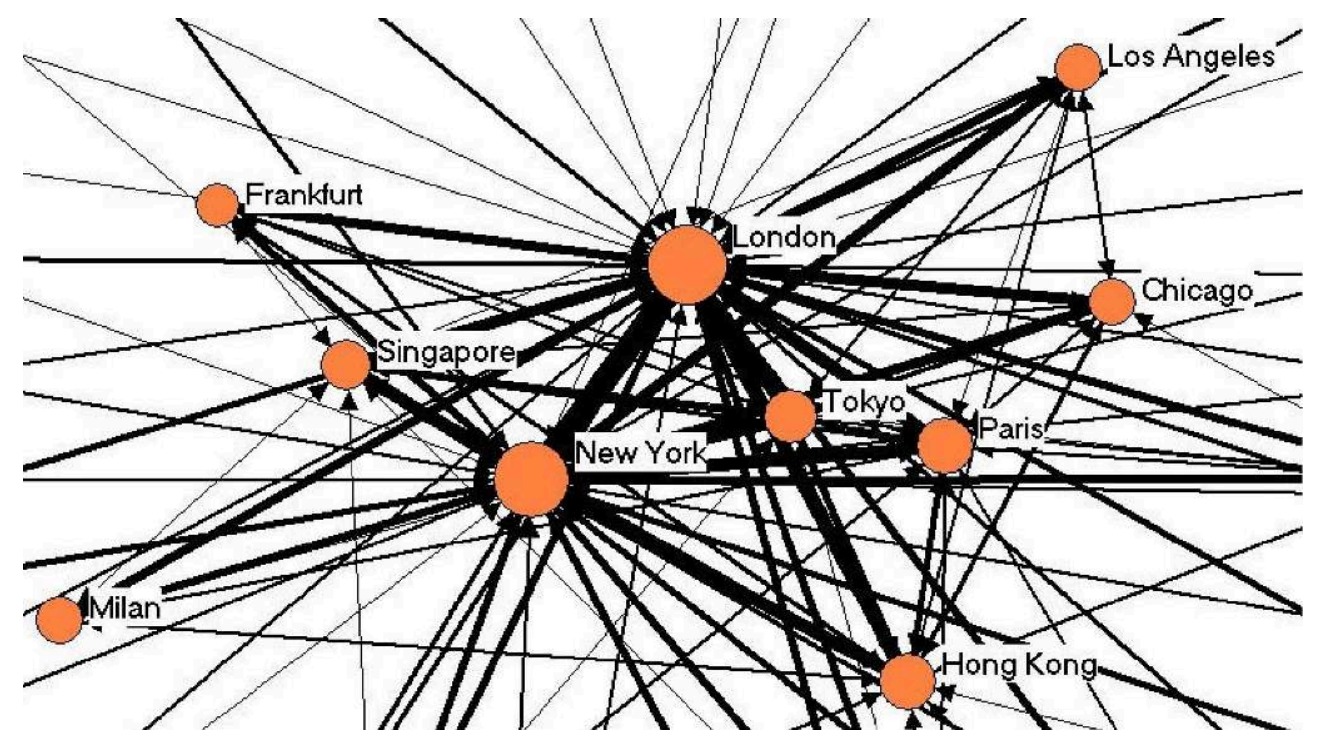

\section{Exploratory analysis of tendencies in the world-city network}

\section{Interaction between hierarchy and regionality}

The various data matrices specified in section 3 represent what Smith and Timberlake (1995, p. 79) have termed "cities in global matrices», and an exploratory analysis of 
these matrices may help in unravelling the basics patterns in the world-city network. This tentative examination can be achieved through different sorts of multivariate data analysis, «[t]his means the wide repertoire of network techniques from elementary derivation of indices to scaling, ordinating, factoring, clustering and blocking» (Taylor, 2001 , p. 192). A clique analysis based on a version of $\mathbf{P}$ paired down to 50 cities has been attempted in Derudder and Taylor (2003); here we will focus on a previous study of Vij where all 234 cities were included (Derudder et al., 2003). In the latter analysis, the data on world-cities has been analysed with a fuzzy clustering algorithm ${ }^{8}$. A total of 22 clusters were derived, which are summarized in Figure 2 and Table 4. In Table 4, the hierarchical tendency in the results is highlighted with clusters listed in terms of average $G$, which is in turn used in Figure 2 to denote five bands around the most important cluster in terms of connectivity. The largest gap in connectivity is between cluster A and band I, but all the bands are identified using gaps in the levels of connectivity. To get a feel for the structure and geography of the classification, Table 4 shows also the size of each cluster and the most typical city in each cluster (i.e. the city with the highest membership degree), while Figure 2 shows two member cities for all arenas to aid in reading the cartogram.

Figure 2. Hierarchical and regional tendencies in the world-city network.

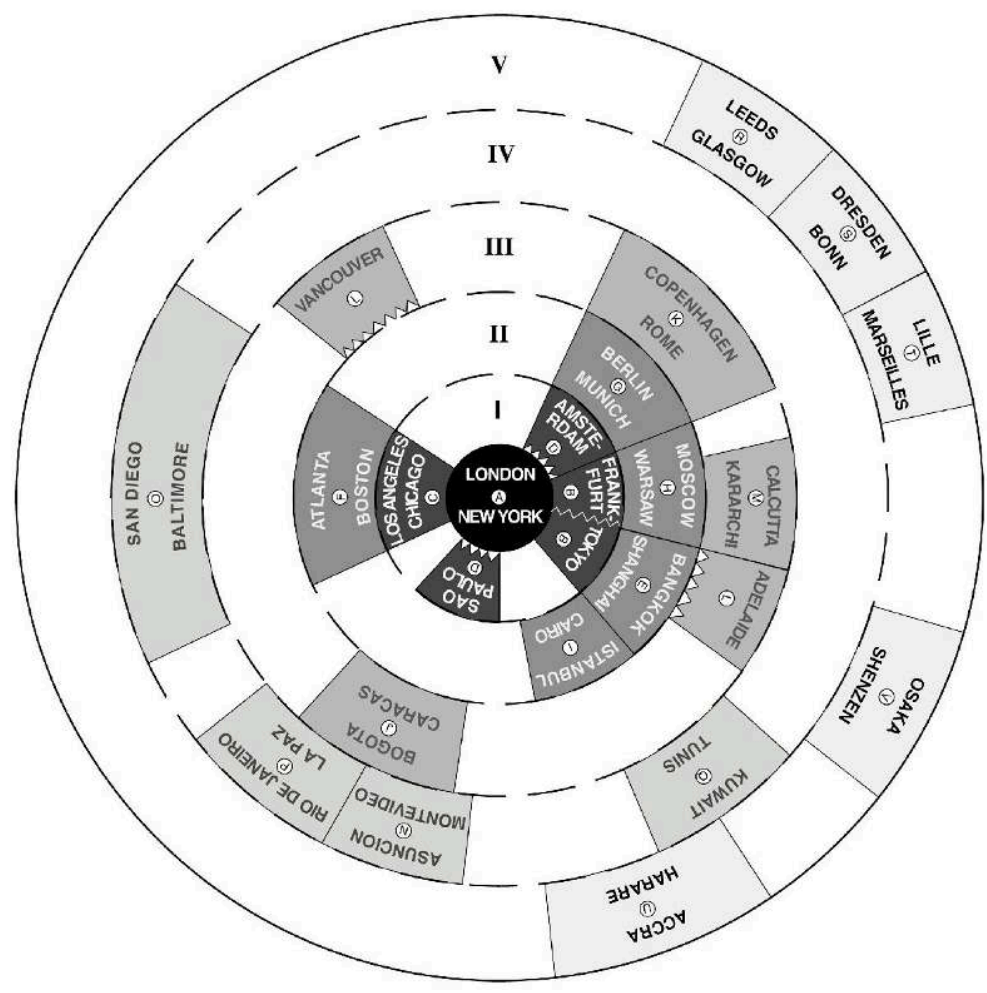


Table 4. Connectivity bands in the world-city network.

\begin{tabular}{|c|c|c|c|c|}
\hline $\begin{array}{l}\text { CLUSTER/ } \\
\text { ARENA }\end{array}$ & $\begin{array}{l}\text { AVERAGE } \\
\text { CONNECTIVITY }\end{array}$ & BAND & $\begin{array}{c}\text { NO. OF } \\
\text { MEMBERS* }\end{array}$ & $\begin{array}{l}\text { TYPICAL } \\
\text { CITY** }\end{array}$ \\
\hline A & 0.988 & Centre & 2 & London \\
\hline B & 0.613 & 1 & 9 & Frankfurt \\
\hline c & 0.574 & 1 & 3 & Chicago \\
\hline D & 0.539 & 1 & 13 & Amsterdam \\
\hline E & 0.438 & $\|$ & 8 & Bangkok \\
\hline $\mathrm{F}$ & 0.401 & $\|$ & 6 & Atlanta \\
\hline G & 0.384 & ॥ & 4 & Berlin \\
\hline H & 0.379 & $\|$ & 6 & Warsaw \\
\hline 1 & 0.371 & ॥ & 14 & Istanbul \\
\hline J & 0.297 & III & 11 & Caracas \\
\hline K & 0.297 & III & 20 & Copenhagen \\
\hline L & 0.231 & III & 29 & Adelaide \\
\hline M & 0.225 & III & 14 & Calcutta \\
\hline$N$ & 0.201 & IV & 13 & Montevideo \\
\hline 0 & 0.193 & IV & 23 & Baltimore \\
\hline$P$ & 0.180 & IV & 26 & La Paz \\
\hline Q & 0.179 & IV & 31 & Kuwait \\
\hline $\mathrm{R}$ & 0.158 & $\mathrm{v}$ & 19 & Leeds \\
\hline $\mathrm{s}$ & 0.157 & v & 8 & Dresden \\
\hline T & 0.148 & v & 16 & Lille \\
\hline$u$ & 0.141 & v & 30 & Accra \\
\hline v & 0.121 & v & 16 & Osaka \\
\hline
\end{tabular}

A detailed overview of the content of the clusters can be found in Derudder et al. (2003), here we will focus on the basic patterns that emerge from this analysis. From Figure 2, it can be seen that the clusters are grouped together in three different ways. First, there is a strong hierarchical dimension to the clusters: cities with similar levels of global network connectivity tend to be classified together (e.g. London and New York in a single cluster). Second, there is a strong regional dimension to the clusters: cities from the same part of the world tend to be classified together (e.g. 18 out of 22 clusters have a discernible «regional» focus). Third, there is a tendency for interaction between these two dimensions: clusters with low average connectivity tend to be more regionally restricted in membership (e.g. clusters with an important «trans-regional» dimension are mainly found in the upper rungs of the world-city network). The latter implies that our results show more than clusters in an abstract «service space», they represent urban arenas in a geographical space that is the world-city network. Hence, as well as the commonplace notion that individual world cities represent critical localglobal nexuses, this analysis suggests that there are also urban arenas that represent regional-global nexuses that may used as alternative descriptions of the different zones (core/semi-periphery/periphery) of the capitalist world-system. The remainder of this section looks at how these general tendencies can be translated into a more refined mapping of the capitalist world-system.

\section{Interaction between world-city and mega-city formation}

Although not working from a world-systems perspective, Harvey (1973) has reminded us that cities can only be understood as a product of specifically social forces set in motion by capitalist relations of production, and, as a consequence, urbanization processes can be expected to diverge in the different zones of the world-economy. The 
way we will look at this contrasting urbanization processes is through the highlighting of the bifurcation between mega-cities and world-cities.

It is of course rather problematic to compare mega-cities and world-cities, since both concepts are built on totally different premises. That is, whereas mega-cities reflect the demographic tradition in urban geography (as epitomized by Zipf's rank-size rule), world-cities reflect the functional tradition in urban geography (as epitomized by Christallers' central-place theory). Nonetheless, it is clear that both notions are somewhat related: obviously there is some tendency for demographically large cities to be economically significant, and this conceptual distinction does therefore not identify discrete classes of cities. New York and Tokyo, for instance, are both mega- and worldcities. Interestingly, however, some researchers have suggested that there is no structural distinction between mega-cities and world-cities. Manuel Castells (1996, Ch. 6) and Hall (2002, p. 114), for instance, have defined world-cities respectively through the number of people that are «functionally connected» to the global economy and in terms of the number of «people served in their hinterland». Moreover, Castells (1996, p. 403 and p. 379) has remarked that mega-cities are located «in a variety of social and geographical contexts», while world-cities are "pervasive» and located «throughout the geography of the planet». As such, world-cities and mega-cities are not necessarily the same, but they do not seem to differ in a structural way.

However, from Figure 3, which regresses population size ${ }^{9}$ (i.e. mega-city formation) versus $G$ (i.e. world-city formation) for 60 «large and significant cities», it can be read that both concepts are in fact very weakly related $\left(\mathrm{R}^{2}=0.0587\right)^{10}$. This weak correlation seems to point to a bifurcation at a structural level in the group of «large» and «significant» cities. Rather than both concepts being somewhat related, then, there seems to be a systematic difference between cities with positive residuals and cities with negative residuals. Put in world-systems terms, the most thorough negative residuals define city-regions dominated by peripheral processes (e.g. Khartoum and Kinshasa), whereas the highest positive residuals define city-regions that are dominated by core processes (e.g. London and New York). Where connectivity and population exhibit a more balanced equilibrium, we find semi-peripheral city-regions (e.g. São Paulo and Istanbul). 
Figure 3. World-Cities versus Megacities.

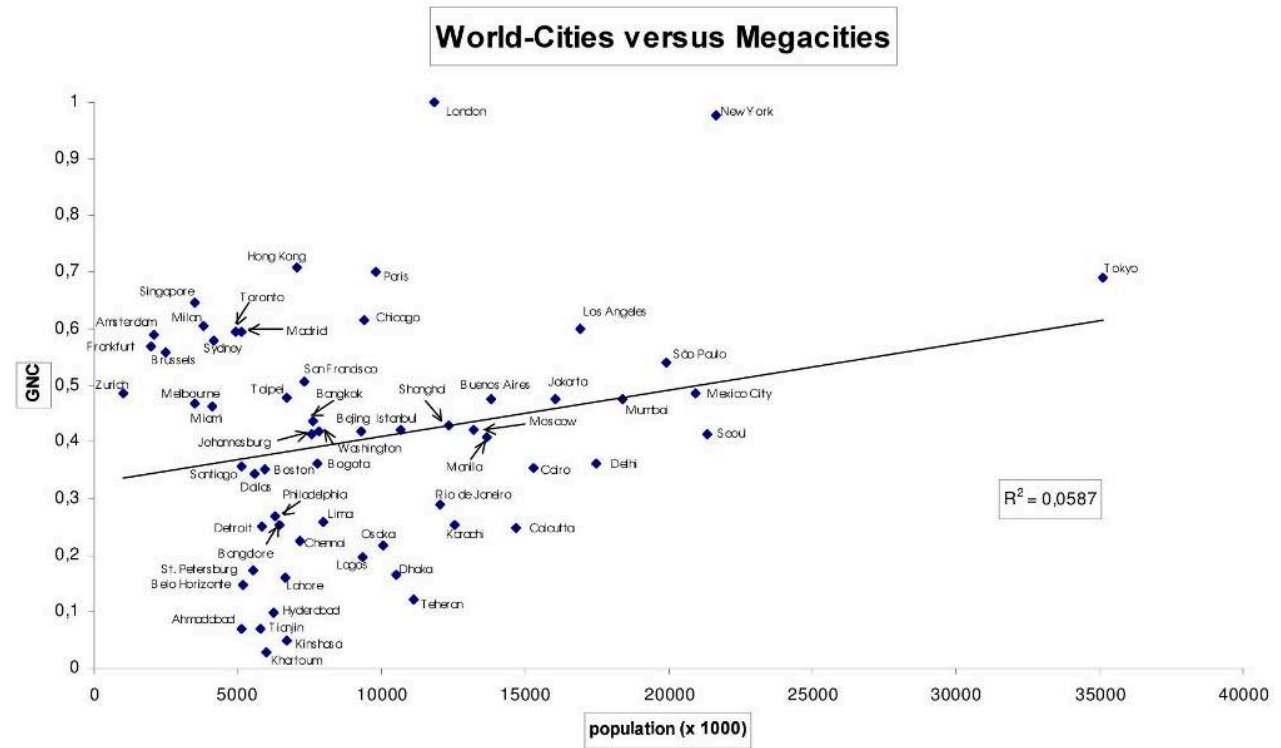

Although this straightforward interpretation may provide the building blocks for an alternative classification of the tripartite division of the world-economy, it can readily be seen that this approach is by all means too simple. Apart from the commonplace remark that these static figures disguise the particular trajectories of each city-region in the development of the world-system, it can be seen that at least two modifications should be made, one empirical and theoretical. First, these data have the tendency to underestimate the connectivity of world-cities in a number of countries, most notably Japan (e.g. Osaka) and the United States (e.g. Detroit). In the case of Japan, protectionist policies of restraining penetration of «external» capital may have resulted in a series of joint ventures, potentially obfuscating the presence of corporate networks in these data. As a consequence, the connectivity of Japanese world-cities may be undervalued because of the wrongly assumed non-presence of a number of global service firms. In the case of the United States, the connectivity of world-cities may be underestimated due to the fact that only "global» service firms were used in the database. There are potentially a number of important US service firms that have had less of an incentive "to go global» because of the sheer scale of the US economy. The connectivity derived from these networks has thus not been included in this analysis, which has in turn led to an underestimation of the world-city status of US cities.

The second modification that needs to be made to an interpretation of Figure 3 is due to the existence of overlapping world-city regions. The suggested "peripherality» of cities like Tianjin and Belo Horizonte, for instance, is for a large part due to the casting shadow of neighbouring world-city regions Beijing and São Paulo. That is, a global service firm may not find it necessary to have a presence in Tianjin or Belo Horizonte since the latter city-regions are also serviced through the neighbouring Beijing and São Paulo office. Following this lead, Tianjin and Belo Horizonte are not "peripheral», but part of the semi-peripheral regions around Beijing and São Paulo. Similarly, second-tier world-cities from the US may be underestimated to the presence of nearby world-cities, e.g. Philadelphia operating in the shadow of New York. 
Obtaining a refined estimate of both modifications is of course very hard, but it can nonetheless be seen that these alterations explain away the "peripherality» of cities such as Osaka, which can be found along the likes of Lagos and Bangalore. Let us, to conclude, briefly focus on China, whose questionable description as being homogeneously (semi)peripheral formed the benchmark example to call for a different approach ${ }^{11}$. In the analysis summarized in Table 4 and Figure 2, we find one Chinese city in Band I (Hong Kong), two cities in Band II (Shanghai and Beijing), and two cities in Band V (Guangzhou and Shenzen). Furthermore, four mega-cities were omitted from this analysis due to their very limited connectivity (Tianjin, Chongqin, Wuhan and Nanjing $)^{12}$. Based on the earlier interpretation of Figure 3 and the proposed modifications on this interpretation, it can be seen that there are three types of cityregions in China. First, there is a region dominated by core processes around thoroughly connected Hong Kong, with neighbouring Shenzen and Guangzhou operating in its shadow. Second, there is a semi-peripheral zone articulated through city-regions Shanghai and Beijing (with Tianjin operating in Beijing's shadow), and third, the central and western parts of the country can be conceived as being dominated by peripheral processes zones. To be sure, this interpretation is by all means very tentative, and Figure 4 therefore merely hints at how a focus on the position a city takes in transnational capital flows may serve as an alternative approach to discerning the different zones in the capitalist world-system.

Figure 4. A tentative mapping of China's place in the capitalist world-system (world-cityness has been derived from the bands in Figure 2).

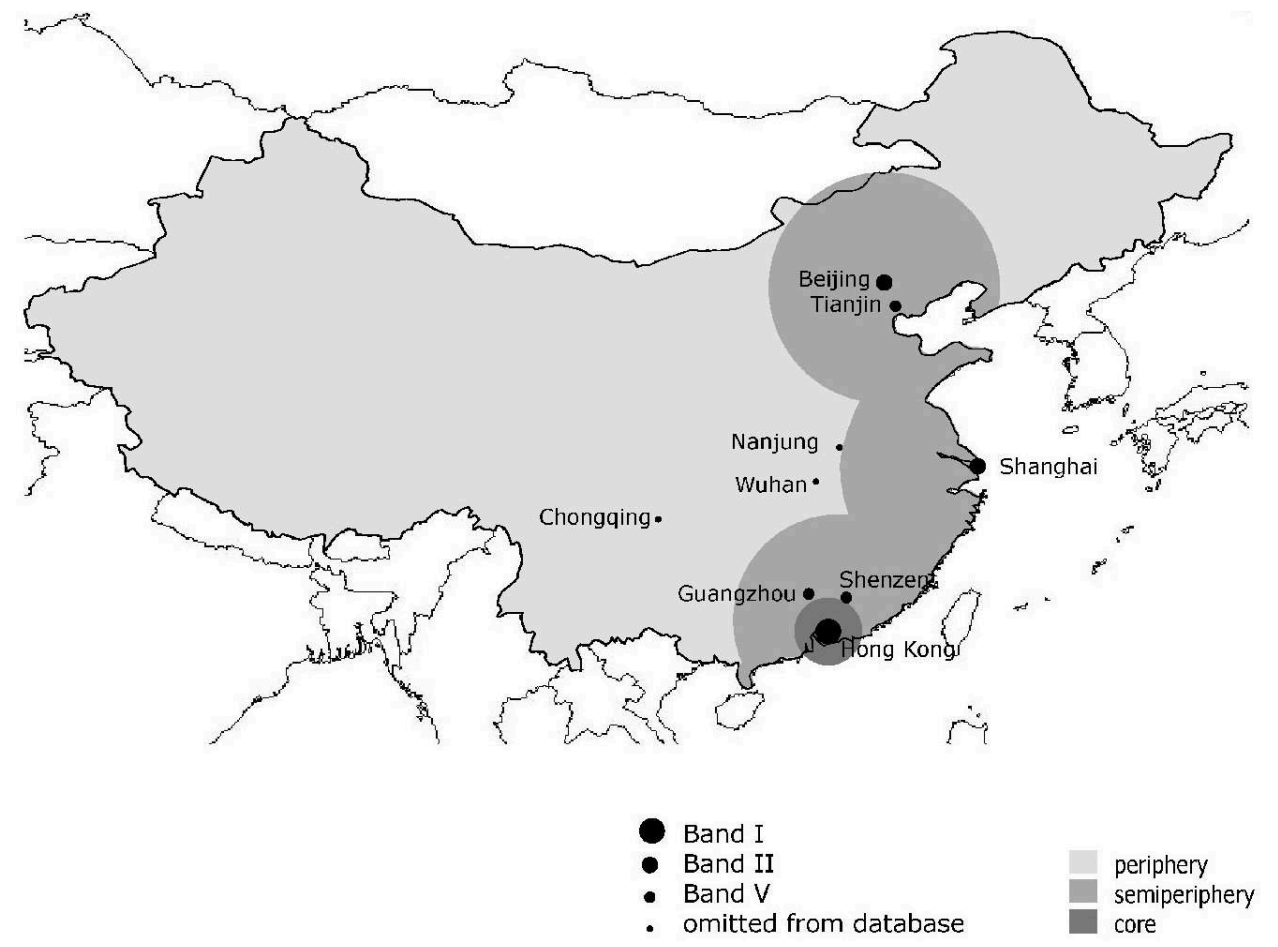

\section{Conclusion}

An overview of seven earlier classification attempts of the tripolar division of the capitalist world-system by Terlouw (1993) has unveiled that there is considerable 
disagreement about where core, semi-periphery and periphery are located. In seven analyses, only two countries were invariably allocated to the semi-periphery (i.e. Venezuela and Chile), while only three countries were invariably allocated to the core (i.e. UK, USA and Germany). Following Giddens (1985), Terlouw (1993, p. 40) has ascertained that this substantial disagreement implies that the concepts of core, semiperiphery and periphery are indicative notions rather than ones that have any precision. In this paper, however, we have sought to look at this significant divergence in terms of the scalar approach taken in these studies ${ }^{13}$. Although commonly viewed as world regions or zones, Wallerstein (1979) has insisted core and periphery represent contrasting bundles of processes that may change over time. It is the uneven geographies of these two bundles which create their expression as core or peripheral zones, and where the processes are mixed the zones are deemed to form the semiperiphery. In terms of our discussion here, world-city formation has been conceived as a core process and the so-called «third world megacity» has been conceived as a peripheral process, and where these come together they create semi-peripheral zones (Taylor, 1999b).

The first results of this global urban analysis are just a simple exploratory tool to describe the zoning of the capitalist world-economy, and this very general assessment thus needs to be explored in more detail. Furthermore, it is clear that a proper implementation of Arrighi's predicaments will have to give far greater weight to (i) the dialectical relation between cities and states and (ii) the historical shifts that have occurred within this dialectical relation throughout the cycles of capital accumulation. In the present paper, these crucial political and historical dimensions have been omitted to allow for a detailed elaboration of the various tendencies present in today's global urban network.

\section{BIBLIOGRAPHY}

ARRIGHI G. (1994), The Long Twentieth Century, London, Verso.

ARRIGHI G. \& DRANGEL J. (1986), «The Stratification of the World System», Review, 10(1), pp. 9-74.

CASTELLS M. (1996), The Rise of the Network society, Oxford, Blackwell.

COHEN R.B. (1981), «The New Inter national Division of Labour, Multinational Corporations and Urban Hierarchy», in DEAR M. \& SCOTT A.J. (eds.), Urbanization and Urban Planning in Capitalist Society, Methuen, London, pp. 287-338.

DERUDDER B. \& WITLOX F. (2002), «Classification techniques in complex spatial databases. On the assessment of a network of world cities», Solstice, XIII(1), pp. 1-32.

DERUDDER B. \& TAYLOR P.J. (2003), «The cliquishness of World Cities», GaWC Research Bulletin, 113, available on-line on http://www.lboro.ac.uk/ gawc/rb/rb113.html. 
DERUDDER B., TAYLOR P.J., WITLOX F. \& CATALANO G. (2003), «Hierarchical tendencies and regional patterns in the world city network: a global urban analysis of 234 cities», Regional Studies, 37(9), pp. 875-886.

DE WACHTER A. (2002), De toepassing van wereldsysteem-analyse op geografische streken. Twee casestudies: de Kempen en noordelijk Ghana, Niet-uitgegeven doctoraatsthesis Universiteit Gent. DODGSHON R.A. (1998), Society in Space and Time, Cambridge, Cambridge University Press. GIDDENS A. (1985), The nation-state and violence, Cambridge, Polity Press.

FRIEDMANN J. (1986), «The world city hypothesis», Development and Change, 17, pp. 69-83.

FRIEDMANN J. (1995), «Where We Stand: a Decade of World City Research», in KNOX P.L. \& TAYLOR P.J. (eds.), World Cities in a World-System, Cambridge University Press, Cambridge, pp. 21-47.

FRIEDMANN J. \& WOLFF G. (1982), «World City Formation: An Agenda for Research and Action», International Journal of Urban and Regional Research, 6, pp. 301-344.

GODFREY B.J. \& ZHOU Y. (1999), «Ranking world cities: multinational corporations and the global urban hierarchy», Urban Geography, 20, pp. 268-281.

HALL P. (2002), «Christaller for a Global Age: Redrawing the Urban Hierarchy», in MAYR A., MEURER M. \& VOGT J. (eds.), Stadt und Region: Dynamik von Lebenswelten, Deutsche Gesellschaft für Geographie, Leipzig, pp. 110-128.

HANNA S.P. (1995), «Finding a place in the world-economy. Core-periphery relations, the nationstate and the underdevelopment of Garrett County, Maryland», Political Geography, XIV(5), pp. 451-472.

HARVEY D. (1973), Social Justice and the City? Baltimore: Johns Hopkins.

HILL R.C. \& KIM J.W. (2000), «Global cities and developmental states: New York, Tokyo and Seoul», Urban Studies, 37, pp. 2167-2195.

KNOX P.L. (1995), «World Cities in a World-System», in KNOX P.L. \& TAYLOR P.J. (eds.), World Cities in a World-System, Cambridge University Press, Cambridge, pp. 3-20.

KNOX P.L. \& TAYLOR P.J. (1995), World Cities in a World-System, Cambridge, Cambridge University Press.

SAEY P. (1996), «Het wereldstedennetwerk: de nieuwe Hanze?», Vlaaams Marxistisch Tijdschrift, 30(1), pp. 120-123.

SASSEN S. (1991), The Global City, Princeton, Princeton University Press.

SASSEN S. (1995), «On concentration and centrality in the global city», in KNOX P.L. \& TAYLOR P.J. (eds.), World Cities in a World-System, Cambridge University Press, Cambridge, pp. 67-78.

SASSEN S. (2000), Cities in a World Economy. Thousand Oaks, Pine Forge Press.

SCOTT A.J. (1997), «The cultural economy of cities», Journal of Urban and Regional Research, 21, pp. 323-39.

SHORT J.R., KIM Y., KUUS M. \& WELLS H. (1996), «The dirty little secret of world cities research data problems in comparative analysis», International Journal of Urban and Regional Research, 20, pp. 697-719. 
SMITH D.A. \& TIMBERLAKE M. (1995), «Cities in Global Matrices: Toward Mapping the WorldSystem's City System"?, in KNOX P.L. \& TAYLOR P.J. (eds.), World Cities in a World-System, Cambridge University Press, Cambridge, pp. 79-97.

SMITH R.G. (2003a), «World city actor-networks», Progress in Human Geography 27(1), pp. 25-44.

SMITH R.G. (2003b), «World city topologies», Progress in Human Geography, 27(5), pp. 561-582.

SNYDER D. \& KICK E. (1979), «The World System and World Trade: An Empirical Exploration of Conceptual Conflicts», Sociological Quarterly, 20(1), pp. 23-36.

STORPER M. (1997), The Regional World, New York, Guilford Press.

TAYLOR P.J. (1997), «Hierarchical Tendencies amongst world cities: a global research proposal», Cities, 14, pp. 323-332.

TAYLOR P.J. (1999a), «So-called 'World Cities': The Evidential Structure within a Literature», Environment and Planning A, 31(11), pp. 1901-4.

TAYLOR P.J. (1999b), «Worlds of Large Cities: Pondering Castells' Space of Flows», Third World Planning Review, 21 (3), pp. iii-x.

TAYLOR P.J. (2000), «World cities and territorial states under conditions of contemporary globalization», Political Geography, 19, pp. 5-32.

TAYLOR P.J. (2001), «Specification of the World City network», Geographical Analysis, 33, pp. 181-194.

TAYLOR P.J. (2002), «Dutch Hegemony and Contemporary Globalization», GaWC Research Bulletin, 83, available on-line on http://www.lboro.ac.uk/gawc/rb/rb83.html.

TAYLOR P.J., HOYLER M., WALKER D.R.F. \& SZEGNER M.J. (2001), «A New Mapping of the World for the New Millennium», The Geographical Journal, 167(3), pp. 213-222.

TAYLOR P.J., CATALANO G. \& WALKER D.R.F. (2002), «Measurement of the World City Network», Urban Studies, 39(13), pp. 2367-76.

TERLOUW C.P. (1992), The Regional Geography of The World-System: External Arena, Periphery, Semiperiphery and Core, Utrecht: Faculteit Ruimtelijke Wetenschap pen Rijksuniversiteit Utrecht. TERLOUW C.P. (1993), «The semiperiphery: focal point of regional development or statistical residue?», in HAUER J. \& HOEKVELD G. (eds.), Moving Regions, Faculteit Ruimtelijke Wetenschappen Rijksuniversiteit Utrecht, Utrecht, pp. 25-42.

WALLERSTEIN I. (1979), The Capitalist World-Economy, Cambridge, Cambridge University Press.

WALLERSTEIN I. (1993), «World system versus World-systems: a critique», in FRANK A.G. \& GILLS B.K. (eds.), The World system: five hundred years or five thousand?, Routledge, London, pp. 292-296.

WALLERSTEIN I. (2000), The essential Wallerstein, New York, The New Press.

\section{NOTES}

1. Apart from being conceived as a proper scale of analysis, this state-based approach is admittedly also due to the baleful abundance of attribute data at the level of the inter-state system (Taylor, 1997, 1999a, see also section 3.a).

2. The difference between Wallerstein and Arrighi is best seen in their alternative concepts of the world-economy. Whereas Wallerstein defines a world-economy as an area with an integrated 
division of labour, Arrighi develops a networked conceptualisation of capitalism. Both conceptualisations can of course very well be alternative descriptions of the same worldeconomy, i.e. Wallerstein emphasizing extensive zonal ranges and Arrighi emphasizing intensive network centres.

3. According to Friedmann (1986, pp. 69-71), the world city network has two levels of hierarchy, which he termed primary (cities such as London) and secondary (cities such as Milan). These two levels, he suggested, are in turn arranged geographically in two ways. First, there is a 'horizontal' division (north - south) defining core and semi-periphery cities showing nine primary cities in the former and only two in the latter (São Paulo and Singapore). Second, there are 'vertical' divisions (east-west) defining three continental sub-systems (parts of Pacific Asia, North America and Western Europe).

4. The notion 'a-territorially organised' refers to the fact that these business organisations explicitly pursue a spatial strategy that allows them to function independently from a single territory (i.e. a single state).

5. This emphasis on the importance of the sub-nodal level can of course be traced back to the observation that cities should not be reified as the producer of flows of capital and information. Rather, it is the aggregated pattern of sub-nodal capitalist agents which defines the relations between world-cities.

6. Initially, a total of 315 cities were selected. The 81 cities least connected were omitted from further analyses, however, because their connectivity measure was potentially too much influenced by the bias resulting from the choice of the 100 firms.

7. In Figure 1, tie strength and node size have been based on rab and $\mathrm{G}$ respectively. To enhance readability, a visualization threshold has been introduced at $\mathrm{rab}=0.2$.

8. The main reason for applying a fuzzy rather than a traditional crisp clustering algorithm can be traced back to the observation that cities in the outer reaches of the world-city network are to be classified based on sparse data. Minor shifts in the sparse data may yield completely different outcomes in the case of a crisp algorithm, and mutually exclusive clusters are therefore unlikely to be unbiased. Furthermore, a fuzzy classification scheme computes degrees of membership rather than mere membership, which has the potential to reflect the intertwined patterns in the world-city network in a more concise manner.

9. Population size has been derived from http://www.citypopulation.de/. The data on the latter website have the distinct advantage that the measurement of all cities has been based on a single (morphological) approach rather than bringing figures together from national data sources that potentially depart from a whole range of different approaches.

10. The 60 cities include the 50 largest agglomerations according to http:// www.citypopulation.de/ plus the ten most connected world-cities that do not figure among these 50 largest agglomerations. The choice of the cities will of course influence the trendline and the associated $\mathrm{R}^{2}$, but it can be expected that the residual patterns remain largely the same.

11. To be sure, the involvement of large Chinese cities in world economy depends for a very large part on their political and administrative functions and other political and historical factors. As a consequence, it is clear that a world-systems interpretation of, say, Beijing's insertion in the world-economy is not solely confined to its insertion in the network of consultancy agencies and other business services.

12. Chongqing, for instance, was omitted from the analysis of 234 cities because of a marginal connectivity comparable to the likes of Havana and Kabul.

13. Another potential reason for the significant disagreement between different authors is the wide range of data used in the different analyses. Whereas Arrighi and Drangel (1986) have restricted themselves to a single indicator (GNP/capita), Terlouw (1992) has presented a worldsystem classification based on a more elaborate approach, including indicators such as trade stability, GDP, military expenditure and the number of diplomats. 


\section{ABSTRACTS}

This paper explores how a geographically detailed assessment of the world-city network may serve as an alternative mapping of the capitalist world-system. The first section of this paper looks at the theoretical rationale for this city-based approach. The second section presents a reinterpretation of the existing body of literature on transnational urban networks in a worldsystems framework, i.e. some of the existing world city-narratives will be re-envisaged as «world-cities in a world-system». Based on this world-systems re-interpretation, the third section provides a formal specification of the world-city network as an inter-locking network where relations between world-cities are defined through the aggregation of relations between sub-nodal capitalist agents. The fourth section elaborates on the general patterns that arise from an exploratory analysis of 234 cities in the capitalist world-system, and hints at how these patterns may serve as an alternative mapping of the tripolar division of the capitalist worldeconomy.

Dit artikel gaat na in welke mate een gedetailleerde analyse van het wereld-stedennetwerk kan gebruikt worden om het kapitalistische wereld-syteem op een alternatieve manier in kaart te brengen. In het eerste deel wordt dieper ingegaan op de theoretische rationale voor deze benadering, het tweede deel herinterpreteert een deel van de bestaande literatuur rond transnationale stedennetwerken in een wereld-syteemkader, i.e. een deel van de bestaande wereldstedenliteratuur zal geïnterpreteerd worden als "wereld-steden in een wereld-systeem». Gebaseerd op deze benadering wordt in het derde deel een formele specificatie van het wereldstedennetwerk gegeven, waarin relaties tussen wereld-steden worden gedefinieerd aan de hand van het geaggregeerde patroon van relaties tussen sub-nodale kapitalistische actoren. Het vierde deel geeft een overzicht van de belangrijkste patronen die naar voorkomen in een analyse van 234 steden in het kapitalistische wereld-systeem, en geeft aan hoe deze patronen kunnen gebruikt worden als de basis voor een alternatieve kartering van de tripolaire structuur van de kapitalistishe wereld-economie.

\section{INDEX}

Keywords: world-systems analysis, world-city network, mega-cities

Trefwoorden wereld-systeemanalyse, wereld-stedennetwerk, mega-steden

\section{AUTHOR}

\section{BEN DERUDDER}

Vakgroep Geografie - Universiteit Gent, ben.derudder@UGent.be 